\title{
Yield and nutrition of tomato using different nutrient sources
}

\author{
Simone Nassau Zuba; Wedson Carlos L Nogueira; Luiz Arnaldo Fernandes; Regynaldo A Sampaio; \\ Cândido A da Costa \\ UFMG-ICA, C. Postal 135, 39404-006 Montes Claros-MG; larnaldo@ufmg.br; rsampaio@ufmg.br; candido-costa@ufmg.br
}

\begin{abstract}
The effect of alternative sources of nutrients was evaluated on yield, nutrition and fruit quality of tomato cv Santa Clara in an agro ecological system, under natural conditions in Montes Claros, Minas Gerais State, Brazil. The experimental design was of completely randomized blocks with seven treatments and four replications, using eight plants per experimental plot. The treatments comprised of 1) conventional fertilization with NPK; 2) organic compost + natural phosphate + rock dust, applied separately; 3 ) organic compost produced from the addition of natural phosphate and rock dust + green manure; 4) organic compost produced from the addition of rock dust + natural phosphate + green manure; 5) organic compost produced from the addition of natural phosphate and rock dust + green manure; 6) natural phosphate + rock dust; and 7) organic compost + natural phosphate + rock dust + green manure. The highest production was obtained using chemical fertilizers. There was no difference among the treatments regarding the content of foliar nutrients and fruit diameter, $\mathrm{pH}$ and total soluble solids. The use of mineral and organic fertilizers significantly reduced the incidence of soft rot and pests in comparison to the use of chemical fertilizers.
\end{abstract}

Keywords: Lycopersicon esculentum, organic fertilization, mineral nutrition.

\section{RESUMO}

Produção e nutrição do tomateiro com diferentes fontes de nutrientes

Com o objetivo de analisar fontes alternativas de nutrientes na produtividade, nutrição e qualidade dos frutos do tomateiro (Lycopersicon esculentum) cv Santa Clara, em sistema agroecológico, no período chuvoso, de setembro a janeiro, conduziu-se um experimento, em condições de campo, no município de Montes Claros-MG. O delineamento experimental foi de blocos ao acaso, com sete tratamentos e quatro repetições. Os tratamentos foram 1) adubação convencional, com NPK; 2) composto orgânico + fosfato natural + pó-de-rocha, aplicados separadamente; 3) composto orgânico, produzido com a adição de fosfato natural e pó-de-rocha + adubação verde; 4) composto orgânico, produzido com pó-de-rocha + fosfato natural + adubação verde; 5) composto orgânico, produzido com fosfato natural e com pó-de-rocha + adubação verde; 6) fosfato natural + pó-de-rocha e; 7) composto orgânico + fosfato natural + pó de rocha + adubação verde. A maior produção foi obtida com o uso de adubos químicos e não houve diferença entre os tratamentos quanto aos teores foliares de nutrientes e diametro, $\mathrm{pH}$ e sólidos solúveis totais dos frutos. $\mathrm{O}$ emprego de adubos orgânicos e minerais reduziu significativamente a incidência de podridão bacteriana e o ataque de pragas no tomateiro em relação aos adubos químicos.

Palavras-chave: Lycopersicon esculentum, adubação orgânica, nutrição mineral.

(Recebido para publicação em 5 de janeiro de 2010; aceito em 29 de outubro de 2010) (Received on January 5, 2010; accepted on October 29, 2010)

$\mathrm{T}$ omato (Lycopersicon esculentum) is a crop with high nutritional requirements and its production is influenced by the availability of nutrients (Ferreira et al., 2003), among other factors. These nutritional requirements are met through the use of nutrient sources which vary depending on the cultural practices adopted by the farmer. The use of conventional or organic sources of nutrients influence in different ways in the farm and, in a prominent way, in the yield and composition of fruits, in the nutrient dynamics and in the soil physical attributes (Toor et al, 2006; Montemurro, 2009).

In this way, Toor et al. (2006) observed the influence of nutrient sources in the chemical composition and flavor of tomato fruits. The same authors have reported greater uptake of macronutrients (N, P and $\mathrm{K})$ in organically fertilized plants in comparison to plants grown with mineral solution. Moreover, Solaiman \& Rabanni (2006) demonstrated agronomical and economic advantages of using organic fertilizers on the tomato crop.

Environmental impacts from the indiscriminate use of fertilizers and pesticides in agriculture, as manifested in cases of poisoning, contamination of waterways and air, and the successive increases in the prices of this inputs have been indicating to researchers, farmers and consumers the necessity of a more sustainable agriculture, which is expected to produce healthier food (Araujo et al., 2001; Tamiso, 2005; Wang, 2006).
Besides the benefits of the reutilization of nutrients and nutritional balance, the use of organic sources of nutrients has contributed to the improvement of soil physical, chemical and biological attributes (Rosen \& Allan, 2007).

The objective of this research was to study the feasibility of using organic and mineral sources as an alternative to conventional chemical fertilizers used for nutrition and production of tomato in the rainy season in the region of Montes Claros, Minas Gerais State, Brazil.

\section{MATERIAL AND METHODS}

This research was carried out in a Red-Yellow Inceptisoil in an 
experimental field at the Pradinho Community (area with $154 \mathrm{~km}^{2}, 16^{\circ}$ $50^{\prime} \mathrm{S}$ and $43^{\circ} 51^{\prime} \mathrm{W}, 16^{\circ} 53^{\prime} \mathrm{S}$ and $43^{\circ}$ $52^{\prime} \mathrm{W}, 16^{\circ} 53^{\prime} \mathrm{S}$ and $43^{\circ} 52^{\prime} \mathrm{W}$ and $16^{\circ}$ $53^{\prime} \mathrm{S}$ and $\left.43^{\circ} 52^{\prime} \mathrm{W}\right)$, between December 2006 and April 2007 in the county of Montes Claros, Minas Gerais State, Brazil. The main climate, according to the Köppen classification, is Aw tropical of savannah with dry winter and humid summer. The native vegetation was the Brazilian savannah (also known as Cerrado), whose chemical analyses, determined according to Embrapa (1997), in the $0-20 \mathrm{~cm}$ layer were: $\mathrm{pH}=$ 6.0 ; organic matter $=47.9 \mathrm{~g} \mathrm{dm}^{-3} ; \mathrm{H}^{+}+$ $\mathrm{Al}^{+3}=32.4 \mathrm{mmol}_{\mathrm{c}} \mathrm{dm}^{-3} ; \mathrm{Al}=0 \mathrm{mmol}_{\mathrm{c}}$ $\mathrm{dm}^{-3} ; \mathrm{K}^{+}=0.56 \mathrm{mmol}_{\mathrm{c}} \mathrm{dm}^{-3}$; P residual $=$ $37.5 \mathrm{mg} \mathrm{L}^{-1}$; P mehlich=14.9 $\mathrm{mg} \mathrm{dm}^{-3}$; $\mathrm{Ca}=68.0 \mathrm{mmol} \mathrm{dm}^{-3} ; \mathrm{Mg}=22.0 \mathrm{mmol}_{\mathrm{c}}$ $\mathrm{dm}^{-3}$; Clay $=300 \mathrm{~g} \mathrm{dm}^{-3}$; Silt $=340 \mathrm{~g} \mathrm{dm}^{-3}$; Fine sand $=330 \mathrm{~g} \mathrm{dm}^{-3}$, Coarse sand $=$ $30 \mathrm{~g} \mathrm{dm}^{-3}$.

The experimental design was randomized blocks with seven treatments and four replications. Each plot consisted of 16 plants spaced $1.0 \mathrm{x}$ $0.5 \mathrm{~m}$, and the useful plot consisted of the four central plants. The treatments consisted of the following fertilizations 1) $30 \mathrm{~g}$ of 4-14-8 and four top-dressings applied each fifteen days 30 days after transplanting with $20 \mathrm{~g}$ of 20-05-20 per hole [this treatment corresponded to the conventional fertilization used by the growers of the Community of Pradinho (control treatment)]; 2) two liters of simple organic compost $+120 \mathrm{~g}$ of rock phosphate and $200 \mathrm{~g}$ of rock dust, applied separately in each hole; 3 ) green manure, two liters of organic compost + 25 g Gafsa phosphate +200 g of rockdust, applied separately in each hole; 4) green manure, two liters of organic compost +10.26 g of rock-dust +120 $\mathrm{g}$ of rock phosphate applied separately in each hole; 5) green manure and two liters of organic compost $+25 \mathrm{~g}$ of Gafsa phosphate $+10.26 \mathrm{~g}$ of rock-dust applied in each hole; 6) $120 \mathrm{~g}$ of phosphate + $200 \mathrm{~g}$ of rock-dust, applied separately in each hole; 7) green manure, two liters of simple organic compost $+120 \mathrm{~g}$ of Gafsa phosphate $+200 \mathrm{~g}$ of rock-dust, applied separately in each planting hole.

The simple organic compost consisted of cotton bolls and cattle manure in a 2:1 ratio, respectively. The composition of each material used in the production of the organic composts is presented in Table 1.

The soil tillage consisted of a plowing and a disking operation and the planting holes were prepared manually. The adopted irrigation system was the furrow irrigation, with an irrigation shift of two days.

In plots where green manure was applied, pigeon pea (Cajanus cajan (L.) Mill) was sown laterally to the planting rows of tomato, spaced 0.5 $\mathrm{m}$ between rows and with a density of 20 seeds per meter, 60 days before application of other treatments and transplanting of tomato seedlings. The plants of pigeon pea were cut 150 days after its planting (flowering stage) and incorporated into the soil. The tomato fruits were harvested 120 days after their transplant.

The tomato plantlets, cv.Santa Clara, were produced in greenhouses, using trays containing commercial substrate $\left(\right.$ Plantmax $\left.^{\circledR}\right)$, and transplanted to the experimental area 27 days after sowing. One single stem of one plant per hole was tutored and periodically disprouted. The ends of the plants were removed when they reached $1.80 \mathrm{~m}$ height.

Spraying with extracts of neem (Azadirachta indica) and the release of Trichogramma sp. for controlling tomato pests were carried out. Biofertilizers and the Bordeaux mixture were used for disease prevention and for providing nutrients to plants, according to the methodology proposed by Fernandes et al. (2005).

The biofertilizer was prepared 30 days before the start of the experiment in the following composition: $430 \mathrm{~g}$ of boric acid, $570 \mathrm{~g}$ of wood ash, 850 $\mathrm{g}$ of calcium chloride, $43 \mathrm{~g}$ of ferrous sulphate, $60 \mathrm{~g}$ of bone meal, $60 \mathrm{~g}$ of meat meal, $143 \mathrm{~g}$ of silicon-magnesium thermo-phosphate, $4.5 \mathrm{~kg}$ of molasses, $30 \mathrm{~g}$ of sodium molybdate, $30 \mathrm{~g}$ of cobalt sulphate, $43 \mathrm{~g}$ of copper sulphate, $86 \mathrm{~g}$ of manganese sulphate, $143 \mathrm{~g}$ of magnesium sulphate, $57 \mathrm{~g}$ of zinc sulphate, $67.5 \mathrm{~g}$ of castor bean meal, 30 drops of iodine solution $1 \%, 500 \mathrm{~mL}$ of cow urine, $20 \mathrm{~L}$ of cow milk, $100 \mathrm{~L}$ of manure, completing the volume to 200
L with water.

At the flowering stage, tomato leaf samples were collected and the amounts of nutrients in plant tissues were determined according to the methodologies proposed by Martinez et al., (1999) and Malavolta et al., (1997), respectively. Analyses of organic fertilizers were carried out according to Kiehl (1985).

The harvest began 134 days after transplanting. The fruits were harvested weekly and evaluated for marketable yield, fruit weight, number of fruits per plant, transversal diameter of the fruit, $\mathrm{pH}$, total soluble solids ( ${ }^{0} \mathrm{Brix}$ ), class of size and type depending on the number of defects.

The $\mathrm{pH}$ was determined in the pure undiluted extract, with a potentiometer and the soluble solids content was determined through a manual refractometer, with results expressed in degrees brix. The diameter and the measures for the classification of fruits according to the size classes were obtained through a digital caliper.

The size classification of oblong fruits was held following the standards of the Brazilian Ministry of Agriculture, Livestock and Supply, into large (transversal diameter greater than 60 $\mathrm{mm}$ ), medium (transversal diameter between 50 and $60 \mathrm{~mm}$ ) and small (transversal diameter between 40 and $50 \mathrm{~mm}$ ).

Towards the defects, the fruits were classified according to type and number of defects, according to the standards of the Ministry of Agriculture, Livestock and Supply, into severe (rot, over-ripened and apical rot) and light (spotted, hollow, warped and immature). The evaluation of the defects caused by the action of insects was done according to the methodology proposed by Ferreira et al., 2004.

All data were subjected to analysis of variance and means were compared by the Scott-Knott test at 5\% of probability.

\section{RESULTS AND DISCUSSION}

There was no statistically significant difference for weight per fruit, fruit 
Table 1. Characteristics of the organic composts used in the experiment $*$ determined from the mass dried at $65^{\circ} \mathrm{C}$ (características dos compostos orgânicos utilizados no experimento * determinados com base na massa seca a $65^{\circ} \mathrm{C}$ ). Montes Claros, UFMG, 2007.

\begin{tabular}{|c|c|c|c|c|}
\hline \multirow[b]{2}{*}{ Attributes } & \multicolumn{4}{|c|}{ Compost type } \\
\hline & Simple & $\begin{array}{l}\text { Enriched } \\
\text { with } \\
\text { rock-dust }\end{array}$ & $\begin{array}{c}\text { Enriched } \\
\text { with } \\
\text { natural } \\
\text { phospate }\end{array}$ & Complete \\
\hline $\mathrm{pH}$ in water & 6.60 & 7.10 & 6.30 & 6.50 \\
\hline $\mathrm{pH}$ in $\mathrm{CaCl}_{2}$ & 6.20 & 6.70 & 6.10 & 6.40 \\
\hline Humidity at $65^{\circ} \mathrm{C}(\%)$ & 4.80 & 3.20 & 3.70 & 3.70 \\
\hline Humidity at $105^{\circ} \mathrm{C}(\%)$ & 10.30 & 6.70 & 7.60 & 7.60 \\
\hline Organic carbon $(\%)^{*}$ & 49.20 & 31.80 & 38.90 & 39.00 \\
\hline Total mineral residue $(\%)^{*}$ & 42.70 & 62.50 & 54.90 & 54.90 \\
\hline Soluble mineral residue $(\%)^{*}$ & 13.20 & 17.90 & 17.80 & 24.40 \\
\hline Insoluble mineral residue $(\%)^{*}$ & 29.60 & 44.60 & 37.10 & 30.50 \\
\hline Nitrogen $(\%)^{*}$ & 1.80 & 1.30 & 1.40 & 1.40 \\
\hline $\mathrm{C} / \mathrm{N}$ ratio $(\%)^{*}$ & 15.90 & 14.20 & 16.10 & 16.10 \\
\hline $\mathrm{P}_{2} \mathrm{O}_{5}(\%)^{*}$ & 0.53 & 0.40 & 1.19 & 3.00 \\
\hline $\mathrm{K}_{2} \mathrm{O}(\%)^{*}$ & 1.00 & 2.81 & 0.88 & 1.17 \\
\hline $\mathrm{CaO}(\%)^{*}$ & 2.05 & 2.22 & 2.81 & 7.88 \\
\hline $\operatorname{MgO}(\%) *$ & 0.77 & 0.56 & 0.64 & 0.73 \\
\hline $\mathrm{S}(\%)^{*}$ & 0.20 & 0.10 & 1.60 & 2.40 \\
\hline $\mathrm{B}(\mathrm{mg} / \mathrm{kg}) *$ & 85.00 & 128.00 & 109.00 & 96.00 \\
\hline $\mathrm{Zn}(\mathrm{mg} / \mathrm{kg}) *$ & 81.00 & 64.00 & 75.00 & 80.00 \\
\hline $\mathrm{Fe}(\%) *$ & 2.11 & 3.96 & 3.18 & 2.46 \\
\hline $\operatorname{Mn}(\mathrm{mg} / \mathrm{kg})^{*}$ & 211.00 & 333.00 & 282.00 & 220.00 \\
\hline $\mathrm{Cu}(\mathrm{mg} / \mathrm{kg}) *$ & 30.00 & 40.00 & 28.00 & 34.00 \\
\hline
\end{tabular}

diameter, $\mathrm{pH}$ and brix, whereas for yield and number of fruits per plant, treatments differed $(p<0.05)$. The greatest values of fruit yield and number of fruits per plant were obtained in the control treatment, which received conventional fertilization with chemical fertilizers, whereas the others did not differ statistically (Table 3).

The yield of treatments with alternative sources of nutrients varied from 28 to $55 \%$ of that obtained in the control treatment (Table 3 ). The highest yield obtained in the treatment with conventional fertilization in comparison to the others and the absence of differences among the treatments with organic and mineral fertilizers can be explained by the high nutritional requirement of the tomato crop in a short period of time. Probably, in the most demanding stage of the tomato crop, organic and mineral sources of "low solubility" used in the "treatments with nutrients absorbed in greater quantity, nitrogen also influences processes involving growth and development, influencing directly on source-sink relations by altering the distribution of assimilates between the vegetative and the reproductive part.

The transformation of organic nitrogen in ammonia and nitrate, which are forms absorbed by plants is slow and can not meet the needs of the plants during the greater nutritional requirement stage (Kiehl, 1993), explaining, perhaps, the lower yield of the treatments which did not received mineral nitrogen. In this sense, the absence of significant differences among these treatments can also be explained.

Although the green manure of faba bean did not meet the tomato demand for nitrogen it may have favored populations of phosphatesolubilizing fungi and bacteria, which play a key role in supplying phosphorus to plants (Silva Filho \& Vidor, 2001). This ability of microorganisms to solubilize phosphates is related to their ability to produce organic acids and extracellular polysaccharides (Kim et al., 1997). Souche et al. (2007) found that microorganisms isolated from the rhizosphere of pigeonpea are effective to solubilize phosphorus from a phosphate rock.

Another factor that may have contributed to the lower yield of tomato plants in treatments with alternative sources of fertilizers was the low dissolution of potassium from the rock-dust. In the case of low-solubility sources, the availability of nutrients can be enhanced by adding these sources in the composting process of organic waste. According to Rodrigues \& Sumioka (2003), Alcantara et al. (2000) and Araújo \& Almeida (1993), the composting process increases the available forms of nutrients to plants. However, in this study, no difference was found among the treatments in which rock-dust and phosphate were applied alone or together with organic wastes for composting (Table 3).

Besides the availability of nutrients, the incidence of pests and diseases might have affected productivity, mainly because the crop was carried out during 
Table 2. Chemical composition of the inputs used in the experiment; $*$ Analytical determinations carried out from dry matter at $65^{\circ} \mathrm{C}$; nd $=$ not determined. **Figures provided by the respective manufacturers (composição química dos insumos utilizados no experimento; *determinações analíticas realizadas na matéria seca a $65 \mathrm{oC}$; nd= não determinado; **valores fornecidos pelos respectivos fabricantes). Montes Claros, UFMG, 2007.

\begin{tabular}{lcccccc}
\hline Components & $\begin{array}{c}\text { Cotton } \\
\text { boll* }\end{array}$ & $\begin{array}{c}\text { Cattle } \\
\text { manure* }\end{array}$ & $\begin{array}{c}\text { Granite } \\
\text { rock-dust }\end{array}$ & $\begin{array}{c}\text { Gafsa natural } \\
\text { phosphate }\end{array}$ & $\begin{array}{c}\text { 4-14-8 } \\
\text { Fertilizer** }\end{array}$ & $\begin{array}{c}\mathbf{2 0 - 5 - 2 0} \\
\text { Fertilizer** }\end{array}$ \\
\hline $\mathrm{C} / \mathrm{N} \mathrm{ratio}$ & 22.50 & 14.30 & nd & nd & nd & nd \\
Total N (\%) & 2.10 & 2.50 & nd & nd & 4.00 & 20.00 \\
$\mathrm{P}_{2} \mathrm{O}_{5}(\%)$ & 0.28 & 1.05 & nd & 28.90 & 14.00 & 5.00 \\
$\mathrm{~K}_{2} \mathrm{O}(\%)$ & 2.03 & 1.33 & 1.32 & 0.14 & 8.00 & 20.00 \\
$\mathrm{CaO}(\%)$ & 1.49 & 1.41 & 35.06 & 60.00 & nd & nd \\
$\left.\mathrm{MgO}^{*} \%\right)$ & 0.58 & 0.89 & 2.62 & 2.00 & nd & nd \\
$\mathrm{SiO}_{2}(\%)$ & nd & nd & 22.70 & nd & nd & nd \\
$\mathrm{AlO}_{3}(\%)$ & nd & nd & 7.01 & nd & nd & nd \\
$\mathrm{Fe}_{2} \mathrm{O}_{3}(\%)$ & nd & nd & 2.51 & nd & nd & nd \\
$\mathrm{Na}_{2} \mathrm{O}(\%)$ & nd & nd & 1.64 & nd & nd & nd \\
$\mathrm{S}_{\left.(\mathrm{g} \mathrm{kg})^{-1}\right)}$ & 0.10 & 0.10 & nd & 32.00 & nd & nd \\
$\mathrm{B}\left(\mathrm{mg} \mathrm{kg}^{-1}\right)$ & 35.00 & 53.00 & nd & nd & nd & nd \\
$\mathrm{Zn}\left(\mathrm{mg} \mathrm{kg}^{-1}\right)$ & 19.00 & 96.00 & nd & 370.00 & nd & nd \\
$\mathrm{Fe}(\%)$ & 0.33 & 1.29 & nd & 0.42 & nd & nd \\
$\mathrm{Mn}\left(\mathrm{mg} \mathrm{kg}^{-1}\right)$ & 57.00 & 243.00 & nd & 27.00 & nd & nd \\
$\mathrm{Cu}\left(\mathrm{mg} \mathrm{kg}^{-1}\right)$ & 10.00 & 40.00 & nd & 19.00 & nd & nd \\
\hline
\end{tabular}

the rainy season. Loss et al. (2004), also working with the cultivar Santa Clara, tutoring one stem per plant, in conventional production system during the rainy season, obtained an average yield of $39.34 \mathrm{t} / \mathrm{ha}$, and attributed this low productivity to losses caused by pests and diseases. In this work, even in the treatments with conventional fertilization, the spraying of pesticides used in conventional crops was not carried out.

A high infestation of whitefly (Bemisia argentifolii) was observed in plants of pigeon pea, whereas an insignificant attack of this insect was found in tomato plants. Picanço et al. (2004), studying the financial impacts of the integrated pest management in tomato, found that the surrounding tracks, such as of pigeon pea in combination with other practices of integrated pest management, reduced the number of insecticide applications. According to the authors, the surrounding tracks act like sources of attraction and habitation for insects including natural enemies of insect pests of the crop.

The diseases that attacked the crop were septoria (Septoria lycopersici), hollow stalk (Erwinia carotovora) and bacterial wilt (Ralstonia solanacearum). Among the pests, we observed a higher incidence of corn earworm (Helicoverpa $z e a$ ), which caused major damage in the early harvests. However, the damage caused by this insect decreased over the crops, probably because of the release of Trichogramma sp in the area of cultivation. Moreover, application of bio-fertilizers may also have provided some control of this insect and other pests. Nunes \& Leal (2001) found positive results in controlling the tomato worm using biofertilizers.

The average weight per fruit of tomato was not affected by treatments, and the average was $105.6 \mathrm{~g}$ (Table 3 ). This value is similar to that obtained by Peixoto (1999), which was $121.5 \mathrm{~g}$.

Regarding the number of fruits per plant, the treatment with conventional fertilization presented the greatest number, whereas the treatments which received alternative fertilization did not differ statistically. In the treatments with conventional fertilization, 20 fruits per plant were obtained, a number very close to that obtained by Peixoto et al. (1999), which was 22.6. In the treatments with alternative fertilization, on average, 9.5 fruits per plant were obtained, which is $52.5 \%$ less than the treatments with conventional fertilization. The lowest number of fruits per plant in the treatments with alternative sources can be attributed to flower abortion, due to the possible plant nutritional deficiency.

The characteristics of fruit quality were defined according to the parameters established for conventional tomatoes, since there are no parameters for the marketing of organic tomato.

According to Ferreira et al. (2004) and Filgueira (2000), the tomato cultivar Santa Clara, for the market, must present a diameter greater than $52 \mathrm{~mm}$. In this study, all treatments presented average values ranging from 53 to $55 \mathrm{~mm}$, given the market demand for this parameter.

For the $\mathrm{pH}$ of the fruit, no pattern was found in comparison to the fresh tomato. In this study, we found that the $\mathrm{pH}$ did not differ among treatments, with values ranging from 4.5 to 4.7 (Table 3 ). According to Ferreira et al. (2005), the $\mathrm{pH}$ of tomato fruits is not changed by the use of organic fertilizer or not.

The flavor of the tomato fruit can be 
Table 3. Total weight of fruit, fruit weight per plant, number of fruits per plant, diameter of fruit, brix and pH of the extract of tomato fruits produced under different fertilization; means followed by the same letter in column do not differ (Scott-Knott, $5 \%$ ); ${ }^{*} \mathrm{C}=$ organic compound, $\mathrm{F}=$ Gafsa phosphate, $\mathrm{P}=$ rock-dust, $\mathrm{V}=$ green manure, $\mathrm{CF}=$ organic compost prepared with Gafsa phosphate, $\mathrm{CP}=$ organic compost prepared with rock-dust and $\mathrm{CFP}=$ organic compost prepared with Gafsa phosphate and rock-dust. **Numbers in brackets represent the percentage of yield of each treatment in relation to the treatment with conventional fertilization (peso total de frutos, peso de frutos por planta, número de frutos por planta, diâmetro do fruto, $\mathrm{pH}$ do extrato e brix de frutos de tomate produzidos sob diferentes adubações; médias seguidas da mesma letra na coluna não diferem entre si (Scott-Knott, $5 \%$ ); ${ }^{*} \mathrm{C}=$ composto orgânico, $\mathrm{F}=$ fosfato de $\mathrm{Gafsa}, \mathrm{P}=$ pó-de-rocha, $\mathrm{V}=$ adubação verde, $\mathrm{CF}=$ composto orgânico preparado com fosfato de $\mathrm{Gafsa}, \mathrm{CP}=$ composto orgânico preparado com pó-de-rocha e $\mathrm{CFP}=$ composto orgânico preparado com fosfato de Gafsa e pó-de-rocha; **números entre parênteses representam a percentagem da produtividade de cada tratamento em relação ao tratamento com adubação convencional). Montes Claros, UFMG, 2007.

\begin{tabular}{|c|c|c|c|c|c|c|}
\hline Treatments* & Marketable yield $\left(\mathrm{t} \mathrm{ha}^{-1}\right)$ & Weight/fruit (g) & Fruits/plant & Diameter (mm) & pH & Brix \\
\hline Control & $44(100 \%)^{* *} \mathrm{a}$ & $110 \mathrm{a}$ & $20 \mathrm{a}$ & $55 \mathrm{a}$ & $4.5 \mathrm{a}$ & $3.5 \mathrm{a}$ \\
\hline $\mathrm{C}+\mathrm{F}+\mathrm{P}$ & $24(55 \%) \quad b$ & $101 \mathrm{a}$ & $12 \mathrm{~b}$ & $54 \mathrm{a}$ & $4.6 \mathrm{a}$ & $3.5 \mathrm{a}$ \\
\hline $\mathrm{CF}+\mathrm{P}+\mathrm{V}$ & $22(50 \%)$ & $110 \mathrm{a}$ & $10 \mathrm{~b}$ & $55 \mathrm{a}$ & $4.6 \mathrm{a}$ & $3.4 \mathrm{a}$ \\
\hline $\mathrm{CP}+\mathrm{F}+\mathrm{V}$ & $22(50 \%)$ & 99 a & $11 \mathrm{~b}$ & $54 \mathrm{a}$ & $4.7 \mathrm{a}$ & $3.2 \mathrm{a}$ \\
\hline $\mathrm{CFP}+\mathrm{V}$ & $13(28 \%)$ & $91 \mathrm{a}$ & $7 \mathrm{~b}$ & $53 \mathrm{a}$ & $4.6 \mathrm{a}$ & $3.5 \mathrm{a}$ \\
\hline $\mathrm{F}+\mathrm{P}$ & $20(45 \%)$ & $112 \mathrm{a}$ & $9 \mathrm{~b}$ & $53 \mathrm{a}$ & $4.6 \mathrm{a}$ & $3.1 \mathrm{a}$ \\
\hline $\mathrm{C}+\mathrm{F}+\mathrm{P}+\mathrm{V}$ & $15(34 \%)$ & $95 \mathrm{a}$ & $8 \mathrm{~b}$ & $55 \mathrm{a}$ & $4.7 \mathrm{a}$ & $3.4 \mathrm{a}$ \\
\hline $\mathrm{CV}(\%)$ & 33.7 & 13.1 & 28.3 & 4.9 & 2.2 & 10.8 \\
\hline
\end{tabular}

Table 4. Classification of tomato fruits according to the size class; averages followed by the same letter in column do not differ (Scott-Knott, $5 \%) ;{ }^{*} \mathrm{C}=$ organic compost, $\mathrm{F}=\mathrm{Gafsa}$ phosphate, $\mathrm{P}=$ rock-dust, $\mathrm{V}=$ green manure, $\mathrm{CF}=$ organic compost prepared with $\mathrm{Gafsa}$ phosphate, $\mathrm{CP}=$ organic compost prepared with rock-dust and $\mathrm{CFP}=$ organic compost prepared with Gafsa phosphate and rock-dust (classificação dos frutos de tomate de acordo com a classe de tamanho; médias seguidas da mesma letra na coluna não diferem entre si (ScottKnott, $5 \%$ ); ${ }^{*} \mathrm{C}=$ composto orgânico, $\mathrm{F}=$ fosfato de Gafsa, $\mathrm{P}=$ pó-de-rocha, $\mathrm{V}=$ adubação verde, $\mathrm{CF}=$ composto orgânico preparado com fosfato de $\mathrm{Gafsa}, \mathrm{CP}=$ composto orgânico preparado com pó-de-rocha e $\mathrm{CFP}=$ composto orgânico preparado com fosfato de Gafsa e pó-de-rocha). Montes Claros, UFMG, 2007.

\begin{tabular}{ccccccc}
\hline \multirow{2}{*}{ Treatment* } & \multicolumn{3}{c}{ Classification (\% of fruits) } & & \multicolumn{2}{c}{ Defects (\% of fruits) } \\
\cline { 2 - 3 } \cline { 6 - 7 } & Small & Medium & Large & & Bacterial rot & Insect attack \\
\hline Control & $5 \mathrm{a}$ & $57 \mathrm{a}$ & $38 \mathrm{a}$ & & $23 \mathrm{a}$ & $24 \mathrm{a}$ \\
$\mathrm{C}+\mathrm{F}+\mathrm{P}$ & $18 \mathrm{~b}$ & $62 \mathrm{a}$ & $20 \mathrm{~b}$ & & $10 \mathrm{~b}$ & $10 \mathrm{~b}$ \\
$\mathrm{CF}+\mathrm{P}+\mathrm{V}$ & $20 \mathrm{~b}$ & $66 \mathrm{a}$ & $14 \mathrm{~b}$ & & $14 \mathrm{~b}$ & $8 \mathrm{~b}$ \\
$\mathrm{CP}+\mathrm{F}+\mathrm{V}$ & $16 \mathrm{~b}$ & $64 \mathrm{a}$ & $20 \mathrm{~b}$ & & $11 \mathrm{~b}$ & $9 \mathrm{~b}$ \\
$\mathrm{CFP}+\mathrm{V}$ & $20 \mathrm{~b}$ & $64 \mathrm{a}$ & $16 \mathrm{~b}$ & & $12 \mathrm{~b}$ & $8 \mathrm{~b}$ \\
$\mathrm{~F}+\mathrm{P}$ & $18 \mathrm{~b}$ & $66 \mathrm{a}$ & $16 \mathrm{~b}$ & & $11 \mathrm{~b}$ & $9 \mathrm{~b}$ \\
$\mathrm{C}+\mathrm{F}+\mathrm{P}+\mathrm{V}$ & $18 \mathrm{~b}$ & $62 \mathrm{a}$ & $20 \mathrm{~b}$ & & $12 \mathrm{~b}$ & $7 \mathrm{~b}$ \\
\hline $\mathrm{CV}(\%)$ & 17,4 & 7,0 & 13,1 & & 23,7 & 21,81 \\
\hline
\end{tabular}

measured by the soluble solids content, expressed by the degree brix. Most tomato cultivars produce fruit with brix ranging from 5.0 to 7.0 (Ferreira et al. 2005). The values obtained in this study ranged from 3.1 to 3.5 . These results are in agreement with Ferreira et al. (2006), who found average values of 3.7 and 3.5, with and without organic manure, respectively. According to these authors, the environmental and cultural conditions given to the tomato plants do not interfere with the content the conventional fertilization.

For the number of defects, according to Brasil (2002), only a serious defect was found, which was associated to the bacterial rot and no light defect was found. The treatment with conventional fertilization showed a higher percentage of fruits with symptoms of bacterial wilt, $23 \%$ in average, compared to other treatments, which did not differ among themselves and had an average of $12 \%$ of fruits with rot symptoms (Table 4).

Fruits produced in the treatment with conventional fertilization presented a higher percentage of fruits with defects associated to entomological attacks ( $24 \%$ on average), whereas the other treatments did not differ and showed an average of $8.5 \%$ of fruits with symptoms (Table 4). According to Leite et al. (2003), the higher availability of nitrogen in the soil promotes a greater amount of amino acids in plant vessels, resulting in a higher attack of insects. Probably, in the treatment with conventional fertilization, the increased availability of nitrogen in soil, as confirmed by its higher content in the leaves, explains the higher incidence of pest attack in this treatment in comparison to the others.

This classification undervaluates commercial organic tomato and does not fit the standard of quality of organic tomato (Ferreira et al., 2005). According to Luz et al. (2007), consumers of 
organic tomatoes accept fruit shapes and colors not accepted in the conventional market and are willing to pay more for them. In this study, fruits with rot symptoms (bacterial wilt) and with defects were discarded from the yield evaluation.

For the foliar nutrients at the flowering stage, there was no statistically significant difference among treatments and the mean values were $50 \mathrm{~g} \mathrm{~kg}^{-1} \mathrm{~N}$, $4.4 \mathrm{~g} \mathrm{~kg}^{-1} \mathrm{P}, 39 \mathrm{~g} \mathrm{~kg}^{-1} \mathrm{~K}, 26 \mathrm{~g} \mathrm{~kg}^{-1} \mathrm{Ca}$, $2.3 \mathrm{~g} \mathrm{~kg}^{-1} \mathrm{Mg}, 6.5 \mathrm{~g} \mathrm{~kg}^{-1} \mathrm{~S}, 38 \mathrm{mg} \mathrm{kg}^{-1}$ B, $29 \mathrm{mg} \mathrm{kg}^{-1} \mathrm{Zn}, 173 \mathrm{mg} \mathrm{kg}^{-1} \mathrm{Fe}, 45 \mathrm{mg}$ $\mathrm{kg}^{-1} \mathrm{Mn}$ and $42 \mathrm{mg} \mathrm{kg}^{-1} \mathrm{Cu}$.

In the treatments with conventional fertilization, in which soluble sources of $\mathrm{N}, \mathrm{P}$ and $\mathrm{K}$ were applied to the soil, the contents of these nutrients in leaves were similar to other treatments, possibly due to the application of low doses of nutrients.

In general, except for nitrogen, foliar nutrient levels were lower than the reference values for the tomato crop, which are, according to Martinez et al. (1999) of: $45.9 \mathrm{~g} \mathrm{~kg}^{-1} \mathrm{~N}, 5.6 \mathrm{~g} \mathrm{~kg}^{-1} \mathrm{P}$, $57.2 \mathrm{~g} \mathrm{~kg}^{-1} \mathrm{~K}, 44.0 \mathrm{~g} \mathrm{~kg}^{-1} \mathrm{Ca}, 5.0 \mathrm{~g} \mathrm{~kg}^{-1}$ $\mathrm{Mg}, 37 \mathrm{mg} \mathrm{kg}^{-1} \mathrm{Zn}, 268 \mathrm{mg} \mathrm{kg}^{-1} \mathrm{Fe}$, $290 \mathrm{mg} \mathrm{kg}^{-1} \mathrm{Mn}$ and $40 \mathrm{mg} \mathrm{kg}^{-1} \mathrm{Cu}$. For phosphorus, the species, cultivar, age of the plant tissue, the nutrient form and the soil attributes affect the levels of nutrients in plant tissues (Muniz et al., 1985). These factors may also influence the leaf levels of other nutrients.

Regarding the visual symptoms of nutritional deficiency, there was a small number of fruits with cracks at the base, probably due to boron deficiency and symptoms of apical rot, probably due to calcium deficiency (Filgueira, 2000). Also conditions of soil moisture and temperature can induce the development of nutritional deficiencies.

Despite the reduced yield provided by the alternative fertilization treatments and the diseases problems, which were aggravated by the rainy season in association to the susceptibility of the cultivar 'Santa Clara' to diseases, we obtained considerable yield in comparison to the national average yield and quality for marketing.

According to Santos \& Noronha (2001), in the studied crop seasons, despite the application of high quantities of pesticides, yield was reduced on 30 and $14 \%$ by fungal diseases and pest attacks, respectively. Only the average cost of pesticides accounted for $28 \%$ of the production. Moreover, these authors inferred that the tomato producers do not care about their health and, also, the lack of technical assistance and the absence of preventive control with crop residues induce an increase in pests and diseases and, consequently, in the indiscriminated use of pesticides.

Since tomato is a crop of high economic risk, product quality and the target market are decisive to the price. Especial products such as organic tomatoes achieve better prices. Furthermore, Mitchell et al. (2007) found that organic tomatoes presents higher levels of flavonoids than the conventional tomatoes. These substances with antioxidant properties help to protect against cardiovascular diseases and some cancers.

\section{REFERENCES}

ALCANTARA FA. 2000. Adubação verde na recuperação da fertilidade de um LATOSSOLO VERMELHO-ESCURO degradado. Pesquisa Agropecuária Brasileira 35: 277-288.

ARAÚJO AP; ALMEIDA DL. 1993. Adubação verde associada a fosfato de rocha na cultura do milho. Pesquisa Agropecuária Brasileira 28: 245-251.

ARAÚJO SMM; LEMOS RNSE; QUEIROZ MER; NUNES GS. 2001. Uso de inseticidas organofosforados nos pólos de produção na ilha de São Luís (MA): Condições de trabalho e contaminação de hortaliças. Pesticidas: $R$. Ecotoxicol e Meio Ambiente 11: 159-179.

BRASIL. 2002. Ministério da Agricultura, Pecuária e Abastecimento. Portaria SARC no 085 de 06 de março de 2002. Propões o Regulamento técnico de identidade e qualidade para classificação do tomate. Diário Oficial [da] República Federativa do Brasil, Brasília, DF. Disponível em: < http://www.agricultura. gov.br/>. Acesso em: 25 jul. 2007.

EMBRAPA. 1997. Empresa Brasileira de Pesquisa Agropecuária. Serviço Nacional de Levantamento e Conservação de Solo. Manual de métodos de análise de solo. Rio de Janeiro: Ministério da Agricultura, 212 p.

FERNANDES MCA; RIBEIRO RLD; MENEZES ELA. 2005. Manejo ecológico de fitoparasitas. In: AQUINO AM; ASSIS RL. Agroecologia: Princípios e técnicas para uma agricultura orgânica sustentável. Brasília: Embrapa Informação Tecnológica, 2005. cap.13, p.275-322.

FERREIRA MMM; FERREIRA GB; FONTES PCR; DANTAS JP. 2003. Produção do tomateiro em função de doses de nitrogênio e da adubação orgânica em duas épocas de cultivo. Horticultura Brasileira 21: 468-473.

FERREIRA MMM; FERREIRA BF; FONTES PCR; DANTAS JP. 2006. Qualidade de tomate em função de doses de nitrogênio e da adubação orgânica em duas estações. Horticultura Brasileira 24: 141-145.

FERREIRA SMR; FREITAS RJS; LAZZARI EN. 2004. Padrão de identidade e qualidade do tomate (Lycopersicon esculentum Mill.) de mesa. Ciência Rural 34: 329-335.

FERREIRA SMR; QUADROS DA; FREITAS RJS. 2005. Classificação do tomate de mesa cultivado nos sistemas convencional e orgânico. Ciência e Tecnologia de Alimentos 25: 584-590.

FILGUEIRA FAR. 2000. Novo manual de olericultura: agrotecnologia moderna na produção e comercialização de hortaliças. Viçosa: UFV, 402p.

HUETT DO; DETTMANN EB. 1991. Nitrogen response surface models of zucchini squash, head lettuce and potato. Plant and Soil 134: 243-254.

KIEHL EJ. 1985. Fertilizantes orgânicos. São Paulo: Agronômica Ceres, cap.11, p.407459.

KIEHL EJ. 1993. Fertilizantes organominerais. Piracicaba: Edição do Autor, 189 p.

KIM KY; JORDAN D; Mc DONALD GA. 1997. Effect of phosphate-solubilizing bacteria and vesicular-arbuscular mycorrihizae on tomato growth and soil microbial activity. Biology and Fertility of Soils 26: 79-87.

LEITE GLD; COSTA CA; ALMEIDA CIM; PICANÇO M. 2003. Efeito da adubação sobre a incidência de traça-do-tomateiro e alternaria em plantas de tomate. Horticultura Brasileira 21: 448-451.

LOSS RA; SILVADJH; FONTES PCR; PICANÇO MC. 2004. Identificação e quantificação dos componentes de perdas de produção do tomateiro. Horticultura Brasileira 22: 238-242.

LUZ JMQ; SHINZATO AV; SILVA MAD. 2007. Comparação dos sistemas de produção de tomate convencional e orgânico em cultivo protegido. Bioscience Journal 23: 7-15.

MALAVOLTA E; VITTI GC; OLIVEIRA SA. 1997. Avaliação do estado nutricional das plantas: Princípios e aplicações. Piracicaba: Potafos, 289p.

MARTINEZ HEP; CARVALHO JG; SOUZA RB. 1999. Diagnose Foliar. In: RIBEIRO AC; GUIMARÃES PTG; ALVAREZ VVH. (ed). Recomendação para uso de corretivos e fertilizantes em Minas Gerais: $5^{a}$ Aproximação. Viçosa, Comissão de fertilidade do solo do Estado de Minas Gerais, p.144-168.

MITCHELL AE. 2007. Ten-year comparison of the influence of organic and conventional crop management practices on the content of flavonoids in tomatoes. Journal of Agricultural and Food Chemistry 55: 6154-6159.

MONTEMURRO F. 2009. Different nitrogen fertilization sources, soil tillage, and crop rotations in winter wheat: Effect on yield, quality, and nitrogen utilization. Journal of 
Plant Nutrition 32: 1-18.

MUNIZ AS. 1985. Nível crítico de fósforo na parte aérea da soja como variável do fator capacidade de fósforo do solo. Revista Brasileira de Ciência do Solo 9: 237-243.

NUNES MUC; LEAL MLS. 2001. Efeito da aplicação de biofertilizante e outros produtos químicos e biológicos, no controle da broca pequena do fruto e na produção do tomateiro tutorado em duas épocas de cultivo e dois sistemas de irrigação. Horticultura Brasileira 19: 53-59.

PEIXOTO JR. 1999. Avaliação de genótipos de tomateiro tipo Santa Cruz no período de verão, em Araguari, MG. Pesquisa Agropecuária Brasileira 34: 2247-2251.

PICANÇO MC; PAULA SV; MORAES JÚNIOR AR; OLIVEIRA IR; SEMEÃOAA; ROSADO JF. 2004. Impactos financeiros da adoção de manejo integrado de pragas na cultura do tomateiro. Acta Scientiarum Agronomy 26: 245-252.

RODRIGUES ET; SUMIOKAAT. 2003. Produção de cará em função de fontes orgânicas de adubação. Ciências Agrotécnica 27: 822828.

ROSEN CJ; ALLAN DL. 2007. Exploring the benefits of organic nutrient sources for crop production and soil quality. Hortechnology 17: 422-430.

SANTOS MM; NORONHAJF. 2001. Diagnóstico da cultura do tomate de mesa no município de Goianópolis. Pesquisa Agropecuária Tropical 31: 29-34.

SILVA FILHO GN; VIDOR C. 2001. Atividade de microorganismos solubilizadores de fosfato na presença de nitrogênio, ferro, cálcio e potássio. Pesquisa Agropecuária Brasileira 36: 1495-1508.

SOLAIMAN ARM; RABBANI MG. 2006.
Effects of N P K S and cow dung on growth and yield of tomato. Bull. Inst. Trop. Agr. 29: 31-37.

SOUCHE EL; ABBOUD ACS; CAPRONI AL. 2007. Solubilização de fosfato in vitro por microorganismos rizosféricos de guandu. Bioscience Journal 23: 53-60.

TAMISO LG. 2005. Desempenho de cultivares de tomate (Lycopersicon esculentum Mill.) sob sistemas orgânicos em cultivo protegido. Piracicaba: ESALQ, 87p. (Dissertação mestrado).

TOOR RK; SAVAGE GP; HEEB A. 2006. Influence of different types of fertilizers on the major antioxidant components of tomatoes. Journal of Food Composition and Analysis 19: 20-27.

WANG SY. 2006. Effect of pre-harvest conditions on antioxidant capacity in fruits. International Conference on Managing Quality in Chains 712: 299-305. 